\title{
Tomislav Zelić
}

Sveučilište u Zadru, Obala kralja Petra Krešimira IV. 2, HR-23000 Zadar

tzelic@unizd.hr

\section{Mediteranizam - kulturni imaginarij Sredozemlja}

\begin{abstract}
Sažetak
Polazeći od pretpostavke da diskursi pod nazivom orijentalizam $i$ balkanizam ne obuhvaćaju u osnovi bogate kulturne odnose između Srednje Europe i Sredozemlja, tvrdim da je potrebno istraživanje trećeg diskursa pod radnim nazivom mediteranizam, t $j$. kulturna imaginacija Sredozemlja kao misaone i književne figure u europskom pismu. Glavna je zadaća razraditi povijest pojma mediteranizam, deducirati heurističke teoretske hipoteze te provesti kontrastivnu i komplementarnu komparaciju ovih triju diskursa. Pritom treba imati na umu da su ta tri diskursa istovremeno isprepletena i suprotstavljena u načinima na koje Europa zamišlja samu sebe. Osim toga, sadrže cijeli niz osjetilnih, osjećajnih i spoznajnih opreka i proturječnosti, koje će se istražiti na odabranim primjerima njemačkih djela novog doba.
\end{abstract}

\section{Ključne riječi}

Europa, Mediteran, Sredozemlje, književnost, filozofija, novo doba, Njemačka, Austrija, mediteranizam

\section{Uvod}

Neke od glavnih hipoteza teorije, koju u nedostatku bolje riječi nazovimo mediteranizam, mogu se heuristički odrediti metodom dedukcije, kontrastivno i komplementarno s obzirom na povijest teorija pod nazivom orijentalizam i balkanizam, po mišljenju Edwarda Wadiea Saida (1935. - 2003.) odnosno Marije Todorove (1949. - ), utemeljitelja znanstvenih teorija o tim diskursima. ${ }^{1}$ U zadanim uskim okvirima ostat ćemo čitateljstvu dužni preispitivanje postavljenih heurističkih hipoteza metodom indukcije na temelju proširenih i produbljenih posebnih istraživanja $» k u l t u r n i h$ imaginacija $\ll^{2}$ o pojedinim autorima, opusima i epohama europskog pisma. Umjesto toga, čitateljstvo će se uputiti na uzorne primjere iz povijesti moderne njemačke filozofije i književnosti. Pritom kulturna imaginacija nije ni čisto realna ni čisto fikcionalna, ali je izvor diskurzivne moći. Može se steći dojam da se Sredozemlje trenutno vraća u javne rasprave što se tiče njegovog zemljopisnog, povijesnog, društvenog te kulturnog značaja za Europu. ${ }^{3}$ Polazište za istraživanja interdisci-

Edward Wadie Said, Orientalism. Western Conceptions of the Orient, Random House, New York 2014. (Edward W. Said, Orijentalizam, prev. Biljana Romić, Konzor, Zagreb 1999.); Maria Todorova, Imagining the Balkans, Oxford University Press, New York 1997.; Maria Todorova, Imagining the Balkans. Updated Edition, Oxford University Press, New York 2009. (Marija Todorova, Imaginarni Balkan, prev. Karmela Cindrić, Naklada Ljevak, Zagreb 2015.).
2

Wolfgang Iser, The Fictive and the Imaginary Charting Literary Anthropology, The John Hopkins University Press, Baltimore - London 1993.; Stuart Hall, Representation. Cultural Representations and Signifying Practices, Sage Publications, London 1997.

Nedavno je njemački germanist Joachim Scholl u intervjuu za njemačku radiostanicu Deutschlandfunk Kultur izjavio da će uoči 
plinarnog područja mediteranistike je epistemološka iritacija uslijed zamora postmoderne teorije, postkolonijalnih i postimperijalnih istraživanja. Prijeko je potrebno pored orijentalizma i balkanizma uzeti u obzir treću diskurzivnu formaciju pod nazivom »mediteranizam «. Treba imati na umu da su kulturni odnosi Europe i njoj suprotstavljenog Drugoga u obliku Orijenta, Balkana i Mediterana složeniji nego što monolitska opreka sugerira. Činjenica je da se sve spomenute regije djelomice poklapaju, odnosno da nije moguće jednoznačno odrediti njihove unutarnje i vanjske granice, bilo to zemljopisno, povijesno ili kulturološki. Za očekivati je da se i tri diskurzivne formacije pod imenom orijentalizam, balkanizam i mediteranizam mogu preklapati, odnosno da se mogu poistovjećivati radi strukturnih analogija retorike i logike filozofijske argumentacije ili poetike i estetike umjetničkog izričaja. A opet, treba pažljivo istražiti i razlike triju spomenutih diskursa te odstupanje svakog pojedinog od druga dva.

U novije vrijeme, primjerice, američki antropolog i etnolog Michael Herzfeld (1947. - ) slijedi postkolonijalni obrazac orijentalizma da bi odredio što je mediteranizam. ${ }^{4}$ No na taj mu način izmiče mediteranizam s pozitivnom konotacijom koji je neupitno ostavio duboke tragove u modernoj povijesti Europe od 18. stoljeća nadalje. Na sličan način, luksemburški germanist Dieter Heimböckel (1961. - ), pri preispitivanju pojma mediteranizam kao književne i misaone figure u okvirima interkulturalne teorije, dolazi do zaključka da se ne radi ni o čemu drugome nego o privjesku postkolonijalnoj teoriji. ${ }^{5}$ Istražujući Camusov pojam mediteranskog mišljenja njemački filozof i politolog Henning Ottmann (1944. - ) ističe cijeli niz dihotomija, isključivih opreka odnosno nepremostivih proturječnosti između Sjevera i Juga, prirode i povijesti, gospodarstva i kulture itd., a prije svega, njemačkog znanja i sredozemnog savoir-vivre, umijeća življenja, ${ }^{6}$ no istovremeno apelira na to da se jedinstvena Europa temelji na pomirbi svih tih dihotomija. ${ }^{7}$ Ottmann ne priznaje da iste kulturne i političke dihotomije razdiru i sjevernjačko i južnjačko shvaćanje Sredozemlja, tj. ideologiju mediteranizma na kojoj počiva duhovno jedinstvo Europe. Uostalom, nerazgraničena područja poput Balkana, Orijenta, Azije ili Mediterana, pogotovo s obzirom na južnu i jugoistočnu Europu, preklapaju se kako zemljopisno tako i kulturološki gledano, a na isti su ili sličan način isprepletene i suprotstavljene i spomenute diskurzivne formacije. Po strani ovdje ostaju rasprave o izrazito složenom i ništa manje spornom pojmu jugoistočna Europa ${ }^{8}$ Prije nego što deduciramo heurističke hipoteze o mediteranizmu, treba podsjetiti na temeljne pretpostavke orijentalizma i balkanizma o Sredozemlju.

\section{Orijentalizam}

Po pitanju zemljopisnog obujma, Said tvrdi da se Orijent, sa stajališta britanskog i francuskog kolonijalizma i imperijalizma 19. i 20. stoljeća, proteže od Sredozemlja do Indije odnosno Kine. ${ }^{9}$ Belgijski povjesničar Henri Pirenne (1862. - 1935.), na kojega se islamofobi pozivaju kada treba izložiti razdor kršćanstva i islama na Sredozemlju nakon povijesne pojave Muhameda i odvajanja srednjovjekovnog kršćanstva od duhovnih izvora na Bliskom istoku, među prvima je ustvrdio, ${ }^{10}$ po Saidovu mišljenju, da se Orijent pretvorio u »odmetnika protiv kojega se podigla cijela europska civilizacija od srednjeg vijeka naovamo.$^{11}$ 
Za razliku od propasti Rimskog Carstva uslijed barbarskih upada, kada su strani načini življenja bili uneseni u starorimsku i sredozemnu kulturu, dok je središte europske kulture srednjeg vijeka i dalje Rim, odnosno Vatikan, kao glavni grad kršćanstva, islamski upadi u 7. stoljeću su, po Pirenneovu mišljenju, imali za posljedicu da je s razvojem »izvorno romansko-german-

gospodarstvene i izbjegličke krize Sredozemlje odlučiti o sudbini Europe te stoga treba početi razmišljati o Europi iz pravca Sredozemlja. Usp. Joachim Scholl, »Literarische Moderne, Das Mittelmeer als Zentrum unseres Schicksals«, Deutschlandfunk Kultur (13. 7. 2015.). Dostupno na: https://www. deutschlandfunkkultur.de/literarische-moderne-das-mittelmeer-als-zentrum-unseres.1270.de.html?dram:article id=325275 (pristupljeno 22. 5. 2020.). Samo dva dana kasnije objavljen je prvi priručnik o mediteranistici na njemačkom jeziku: Mihran Dabag et al. (ur.), Handbuch der Mediterranistik. Systematische Mittelmeerforschung und disziplinäre Zugänge, Wilhelm Fink - Ferdinand Schöningh, München - Tübingen 2015.

Michael Herzfeld, »The Horns of the Mediterraneanist Dilemma«, American Ethnologist 11 (1984) 3, str. 439-454; Michael Herzfeld, »Of Horns and History. The Mediterraneanist Dilemma Again«, American Ethnologist 12 (1987) 4, str. 778-780; Michael Herzfeld, "Performing Comparisons: Ethnography, Globetrotting, and the Spaces of Social Knowledge«, Journal of Anthropological Research 57 (2001) 3, str. 259-276.

Dieter Heimböckel, »Zwischen Projektion und Dekonstruktion. Mediterranismus oder Vom Nutzen und Nachteil einer Denkfigur zur Erforschung des 'südlichen Blicks'", Zeitschrift für interkulturelle Germanistik 8 (2017), str. 74-86.

6

Henning Ottmann, »Mediteransko mišljenje «, prev. Pavo Barišić, Filozofska istraživanja 35 (2015) 1, str. 49-52.

7

Ibid., str. 52.

Naime, na njemačkom govornom prostoru, pojam Südosteuropa uveo je austrijski diplomat i albanolog Johann Georg von Hahn (1811. - 1869.) tek 1863. godine nakon putovanja rijekama Drinom i Vardarom. Usp. Johann Georg von Hahn, Reise durch die Gebiete des Drin und Wardar im Auftrage der kaiserlichen Akademie der Wissenschaften unternommen im Jahre 1863, Kaiserlich-Königliche Hofund Staatsdruckerei, Beč 1867. Pojam Jugoistočnoeuropski poluotok (Südosteuropäische
Halbinsel) točniji je od diletantskog pojma Balkanski poluotok (Balkanhalbeiland, usp. August Zeune, Geo, Versuch einer wissenschaftlichen Erdbeschreibung, Wittich, Berlin 1808., str. 76), tvrdi Hahn kako bi ispravio krivu zemljopisnu predodžbu da se Balkanska gora proteže sve do Jadranskog mora. Nakon toga, zemljopisni pojam Südosteuropa koristi se sinonimno pojmu Balkan, s tim da za vrijeme austro-ugarske vladavine označava europske teritorije osvajane od strane Osmanskog Carstva, dok Zapadna Europa najkasnije uoči Prvog svjetskog rata počinje izdvajati jugoistočnu Europu od kontinentalne Europe. Usp. Larry Wolff, Inventing Eastern Europe. The Map of Civilzation on the Mind of the Enlightenment, Stanford University Press, Stanford 2010., str. 114, 366, u pogledu na William Miligan Sloane, The Balkans. A Laboratory of History, Eaton \& Mains, New York 1914., str. vii, viii, 3, 56. No pojam Südosteruopa u njemačkom je govornom prostoru diskreditiran zbog toga što je korišten u okvirima »težnje za Istokom« (Drang nach Osten) i "politike životnog prostora" (Lebensraumpolitik) nacionalsocijalizma. Usp. M. Todorova, Imaginarni Balkan, str. 27ff. Usp. Tanja Petrović, Yuropa. Das jugoslawische Erbe und Zukunftsstrategien in postjugoslawischen Gesellschaften, Verbrecher Verlag, Berlin 2015., str. 27. Međutim, uoči pada komunizma u sklopu kulturnopolitičkih intervencija znanosti za društveni red i mir u tranzicijsko doba oko 1989. godine, kad se pojačano osnivaju istraživačke ustanove za znanstveno istraživanje jugoistočne Europe pod nazivom Südosteuropa-Institut, pojam Südosteuropa poprima politički neutralno značenje. Usp. Uwe Hinrichs, Uwe Büttner (ur.), Die Südosteuropa-Wissenschaften im neuen Jahrhundert. Akten der Tagung vom 16.-19.10.1999 an der Universität Leipzig, Harrasowitz Verlag, Wiesbaden 2000., str. 83. U Hrvatskoj je rasprava o Balkanu i Jugoistočnoj Europi također odjeknula. Usp. Anđelko Milardović, Zapadni Balkan. Fragmenti o ideologiji i politici Zapada, Pan liber, Zagreb 2009. Usp. Pavo Barišić (ur.), Demokracija na prekretni$c i$, Hrvatsko filozofsko društvo, Zagreb 2014

E. Said, Orijentalizam, str. 57.

10

Usp. Henri Pirenne, Mohamed and Charlemagne, prev. Bernard Miall, W. W. Norton \& Co., New York 1939 
ske civilizacije ${ }^{12}$ središte europske kulture pomaknuto sa Sredozemlja, tada samo jedne arapske provincije, na sjever Europe. Svejedno je Pirenne, po Saidovu mišljenju, dionik orijentalizma s negativnom konotacijom, utoliko što propušta uvidjeti da Zapad, pri izgradnji obrane od islama, istovremeno crpi islamsku filozofiju i znanost te da je islamski doprinos Zapadu sustavan i temeljit $\mathrm{i}$ to ne samo u negativnom smislu dijalektičke suprotnosti i zakletog neprijateljstva. ${ }^{13}$

Prema tome, Said može isticati paradoks da se Orijent i islam »uvijek predstavljaju kao odmetnici koji će odigrati posebnu ulogu $u$ Europi ${ }^{14}{ }^{14} \mathrm{Sa}$ zapadnoeuropskog stajališta o kulturi i društvu na Bliskom istoku, pojavljuje se orijentalizam kao sustav znanja i znanosti koji je izvor okcidentalne moći, vladavine i autoriteta nad Orijentom, Bliskim istokom, odnosno Arabijom, a orijentalistička je znanost popraćena eurocentrističkim osjećajem nadmoći Zapada nad Istokom. Tim znanjem i osjećajem ponosi se politička, intelektualna i akademska kultura novog doba u Zapadnoj Europi. Orijentalizam stvara svoje vlastite oblike i odnose između moći i znanja, određivanja i poistovjećivanja, raspravljanja i svladavanja »dvojnih oprečnosti, gdje jedan termin vlada nad drugim «. ${ }^{15} \mathrm{U}$ većini slučajeva radi se o uzajamno isključivom suprotstavljanju navodno prosvijetljene kulture na Zapadu i navodno misterioznog i prijetećeg barbarstva na Istoku. Said naglašava da orijentalizam predstavlja stari običaj europske kulture utemeljen posebice u neprijateljstvu Europe prema islamu, premda je dihotomija između Europe i Orijenta, smatra, samo ideološka konstrukcija bez utemeljenosti u ontologiji i epistemologiji. ${ }^{16}$ Orijent je, po Saidovu mišljenju, europska izmišljotina bez ikakvog pokrića u stvarnosti. U kasnije dodanom uvodu iz 2003. godine Said donosi zaključak kako zamišljanje Orijenta diskurzivno utječe na europsko poistovjećivanje:

»Orijent nije samo susjedan Europi; već je on isto tako mjesto najvećih, najbogatijih i najstarijih europskih kolonija, izvor njezinih civilizacija i jezika, njezin kulturni suparnik, jedna od njezinih najprodubljenijih i najpovratnijih predodžbi o Drugome. « ${ }^{17}$

Povrh toga, Said istražuje odnos kolonijalnih sila i kolonija na Bliskom istoku tvrdeći da takozvani »akademski orijentalizam $\aleph^{18}$ na znanstvenim poljima orijentalistike $\mathrm{i}$ islamskih studija pridonosi omalovažavanju »subalternog subjekta $\ll,{ }^{19}$ kako ga je nazvala indijska filozofkinja Gayatri Chakravorty Spivak (1942. - ). U kulturološko-semantičkom smislu, stranac, odnosno veliki Drugi, pritom utjelovljuje kulturnu različitost kao alijenitet, ono sasvim drugačije od svega drugoga, za razliku od alteriteta, onoga što je nepoznato, strano ili tuđe, no što se svejedno može upoznati, otkriti, prisvojiti ili osvojiti kao vlastitost i svojstvenost. ${ }^{20}$ Said zaključuje da orijentalizam posjeduje sva obilježja negativnog egzotizma i kulturološkog rasizma, imperijalizma i drugih oblika dogmatizma. ${ }^{21}$ Premda je Said u pravu da »akademski orijentalizam $\ll^{22}$ zlorabi i ponižava znanost kao sredstvo izvršavanja sile i nasilja, održavanja moći i vladavine, autor ovih redaka je mišljenja da politički angažman postkolonijalne teorije $u$ društvenom sustavu znanosti nije ništa manje problematičan. Štoviše, u povijesti njemačke i austrijske književnosti postoje mnogobrojni primjeri orijentalizma s izrazito pozitivnom konotacijom. ${ }^{23}$ Usprkos tomu, Saidovu kulturnu imaginaciju o njemačkom orijentalizmu opsjeda Karl Wilhelm Friedrich Schlegel (1772. - 1829.) i scenarij kako taj mladi njemački romantičar 1803. godine sjedi za pisaćim stolom u nacionalnoj biblioteci Louvre u Parizu i izučava sanskrt. ${ }^{24}$ Povrh toga, što se tiče istraživanja mediteranizma, Said ne uzima u obzir da je osvajanje Sredozemlja tijekom 15. i 16. stoljeća bilo neizostavna pretpostavka za britanski kolonijalizam i imperija- 
lizam na Bliskom istoku. Tu povijesnu činjenicu istaknuli su, među ostalima, francuski povjesničar Fernand Braudel i britanski povjesničar sicilijanskih korijena David Abulafia. ${ }^{25}$

\section{Balkanizam}

Američka povjesničarka i balkanologinja bugarskog porijekla Maria Todorova, poznata po već spomenutim istraživanjima o balkanizmu, po pitanju zemljopisnog raspona navodi da za vrijeme Balkanskih ratova 1912. - 1913. godine Balkan predstavlja »europski mediteranski poluotok «. ${ }^{26}$ Zemljopisno gledano, Sredozemlju se ne mogu osporiti »istočne, južne i zapadne granice određene Crnim, Mramornim, Egejskim, Sredozemnim, Jonskim i Jadranskim morem «. ${ }^{27} \mathrm{U}$ namjeri da istraži odnos kulturoloških izmišljotina i povijesne stvarnosti, Todorova se vodi poznatom krilaticom austrijskog grofa Hermanna Keyserlinga (1880. - 1946.): »Da Balkan ne postoji, trebalo bi ga izmisliti. ${ }^{28}$ No, Todorova smatra da zza razliku od neopipljivog Orijenta, Balkan postoji kao konkretna povijesna i zemljopisna činjenica «. ${ }^{29}$ Stoga se Balkan ne može jednostavno svesti na »tipične strukture (i njihove ideološke sklonosti)« u smislu orijentalizma po Saidu. ${ }^{30}$

11

E. Said, Orijentalizam, str. 92.

12

Ibid.

13

Edward Said, »The Clash of Ignorance«, The Nation (22. 10. 2001.). Dostupno na: https:// www.thenation.com/article/archive/clash-ignorance/ (pristupljeno 27. 5. 2020.).

14

E. Said, Orijentalizam, str. 93.

15

Jacques Derrida, Positions, prev. Alan Bass, University of Chicago Press, Chicago 1982., str. 41 .

16

E. Said, Orientalism, str. 2.

17

E. Said, Orijentalizam, str. $7 \mathrm{f}$.

18

E. Said, Orientalism, str. 2.

19

Gayatri Chakravorty Spivak, Can the subaltern speak?, Macmillan, Basingstoke 1988.

20

Horst Turk, »Alienität und Alterität als Schlüsselbegriffe einer Kultursemantik«, Jahrbuch für internationale Germanisik 22 (1990), str. 8-31.

21

E. Said, Orijentalizam, str. 15.

\section{2}

Ibid., str. 8 .

23

Alexandra Polaschegg, Der andere Orientalismus, Regeln deutsch-morgenländischer Imagination im 19. Jahrhundert, Walter de Gruyter, Berlin - New York 2005.

24

E. Said, Orijentalizam, str. $128 \mathrm{f}$.

25

Fernand Braudel, Sredozemlje i sredozemni svijet $u$ doba Filipa II., prev. Đurđa ŠinkoDepierris, Mirna Cvitan Černelić, Jagoda Milinković, Izdanja Antibarbarus, Zagreb 1997. - 1998.; David Abulafia, Das Mittelmeer. Eine Biographie, S. Fischer, Frankfurt na Majni 2013.

26

M. Todorova, Imagining the Balkans, str. 3.

27

M. Todorova, Imaginarni Balkan, str. 58, navodeći kao izvor The New Encyclopaedia Britannica iz 1993. godine.

28

M. Todorova, Imaginarni Balkan, str. 195, s obzirom na: Count Hermann Keyserling, Europe, prev. Maurice Samuel, Harcourt \& Brace, New York 1928.

29

Ibid., str. 28.

30

E. Said, Orijentalizam, str. 261. 
Po uzoru na Saida, Todorova ipak tvrdi da je i balkanizam stari običaj u zapadnoeuropskoj i srednjoeuropskoj kulturi 20. stoljeća. Ideološke konstrukcije Balkana mitologizirane su i nastavljaju se pojavljivati do danas. Diskurzivna formacija pod nazivom balkanizam sadrži svojevrsne osjetilne, osjećajne i spoznajne opreke i proturječnosti. Naime, Balkan je zemljopisno nerazdvojivo područje na europskom kontinentu. No, Europa diskurzivno konstruira Balkan kao nepoznato, strano i tuđe, tj. alteritet, ili djelomice odnosno sasvim drugačije od svega drugoga, tj. alijenitet, s čime se Europa sama poistovjećuje. Balkan služi Europi kao neka vrsta repozitorija negativnih svojstava, možda djelomice i svojih vlastitih svojstava iz prošlosti, koju kolektivna svijest potiskuje u sadašnjosti. Pomoću tih kulturnih imaginacija Europa stvara pozitivnu, djelomice čak i samodopadnu i narcisoidnu sliku o samoj sebi. ${ }^{31}$ Sama je riječ Balkan daleko od bezazlenog zemljopisnog naziva za jedno europsko područje. Početkom 20. stoljeća i nadalje, a pogotovo za vrijeme rata u Hrvatskoj i Bosni i Hercegovini, postala je rasprostranjenim pejorativnim šlagvortom $s$ dalekosežnim utjecajem u javnim raspravama. U suvremeno doba, riječ Balkan i dalje nosi negativnu konotaciju osuđivanja, grubosti, surovosti, nasilnosti, pretjerane strastvenosti, sklonosti sukobljavanju i rasipnosti, razvojne zaostalosti i nazadnosti, korupcije i kriminala. Tako je krilatica o bačvi baruta na Balkanu, nastala za vrijeme Prvog svjetskog rata, ušla u svakodnevnu uporabu, a glagolizacija balkanizirati i apstrakcija balkanizacija postoje gotovo u svim europskim jezicima. Međutim, nemaju isključivo političku konotaciju, nego služe kao takozvane mrtve metafore za bilo koju vrstu rascijepa u društvenom ili kulturnom području, pri čemu i dalje zadržavaju negativnu konotaciju.

Teorija balkanizma, smatra autor ovih redaka, problematična je za istraživanje mediteranizma u europskoj kulturi utoliko što je Mediteran, kao i Balkan, zemljopisno nerazdvojivo spojen s europskim kontinentom. Uz dvojakost mora i kopna, koja sama po sebi nameće konstrukciju da je jedno drugome nepoznato, strano, tuđe te posve drugačije, spomenimo i mnoštvo kulturoloških različitosti i sličnosti Europe i Sredozemlja.

\section{Mediteranizam}

Što se tiče povijesti pojma mediteranizam ${ }^{32} \mathrm{u}$ fragmentima, a uoči Prvog svjetskog rata, treba istaknuti da se taj naziv, prije svega, odnosi na rasno-biološko uvjerenje da su Sjevernjaci u svim pogledima nadmoćni Južnjacima. O nauci pod nazivom mediteranizam razmišljali su velikani upitnih znanstvenih zasluga na polju rasne biologije, koja je nastala na temeljima teorije evolucije Charlesa Darwina (1809. - 1882.) koncem 19. stoljeća i djelovala neprekidno do sredine 20. stoljeća u Velikoj Britaniji odnosno u Sjedinjenim Američkim Državama. ${ }^{33}$ Svima njima zajedničko je da u pogledu stare Europe razlikuju nordijsku rasu vladara, odnosno »arijsku rasu« od južnjačke rase robova, odnosno »mediteranske rase«. Na temelju monolitnog suprotstavljanja dihotomije Sjevera i Juga Europe veličaju Sjevernjake i omalovažavaju Južnjake. ${ }^{34}$ Udarac zagovarateljima rasno-biološkog suprematizma zadaje talijanski paleontolog Giuseppe Sergi (1836. - 1941.). U svom glavnom djelu pod nazivom The Mediterranean Race. A Study of the Origins of European Peoples (Mediteranska rasa. Istraživanje o ishodištu europskih naroda), iz 1901. godine, postavlja teorijsku hipotezu o takozvanoj depigmentaciji. ${ }^{35}$ Po njoj, nordijci se i južnjaci, biološki gledano, ni u čemu ne razlikuju. Sjevernjaci 
su, navodno, izgubili nekoliko nijansi tamnoće kože Južnjaka zbog manjka izloženosti suncu. Sergi na lukav i domišljat način iznosi tvrdnju da svi Europljani uistinu pripadaju »mediteranskoj rasi«. Na taj način zagovara rasnobiološko jedinstvo svih Europljana kao pripadnika »mediteranske rase«, dok njegovi protivnici iz Velike Britanije i SAD-a neopravdano dijele Europljane na Sjevernjake i Južnjake. Međutim, problematično je što Sergi očito polazi od istih ili sličnih pretpostavki kao i pseudoznanstvena rasna biologija. ${ }^{36}$

U povijesti njemačke književnosti od 18. stoljeća nadalje, Johann Gottfried Herder (1744. - 1803.) prvi je spoznao značaj Sredozemlja za razvoj pomorstva i trgovine u Europi. U duhu građanskog liberalizma, a kao posljedica

31

Usp. Tomislav Zelić, »Habermas and his Yugoslavia«, u: Robert Lee (ur.), Germany and the Imagined East, Cambridge Scholars Publishing, Newcastle 2005., str. 50-68; Daniela Finzi, Unterwegs zum Anderen? Literarische Erfahrungen der kriegerischen Auflösung Jugoslawiens aus deutschsprachiger Perspektive, A. Francke, Tübingen 2013.; Boris Previšić, Literatur topographiert. Der Balkan und die postjugoslawische Krieges im Fadenkreuz des Erzählens, Kulturverlag Kadmos, Berlin 2014

32

U hrvatskoj znanosti, filologiji, etnologiji i folkloristici, pojam mediteranizam koristi se uglavnom heuristički, bez utemeljenosti $u$ povijesnim i sustavnim istraživanjima. Usp. Simona Delić, »Poetika domaćeg internacionalizma u komparativnom proučavanju hrvatske propovjedne pjesme, balkanska balada, mediteranski folkloristički vidici«, Narodna umjetnost 36 (1999) 1, str. 253-266; Sanjin Sorel, »Tradicija i mediteranizam u poeziji«, Croatica et Slavica Iadertina 3 (2007) 3, str. 359-368; Anastazija Komljenović, »Stilski sustavi pjesničkog idioma Krune Quiena«, Croatica et Slavica Iadertina 9 (2013) 2, str. 451-465; Sanja Knežević, Mediteranski tekst hrvatskog pjesništva, Naklada Ljevak, Zagreb 2013.

33

U rasno-biološku raspravu o mediteranizmu bili su uključeni i ugledni pravnici, ekonomisti, medicinari, eugeničari, etnolozi, antropolozi i paleontolozi. Glavni je glasnogovornik u Velikoj Britaniji bio Thomas Henry Huxley (1825. - 1895.), poznat pod nadimkom »Darwinov buldog«. Među američkim pristašama tog pokreta treba izdvojiti pravnika i eugeničara Arthura de Gobineaua (1816. - 1882.), poznatog kao suosnivača nauke o nadmoći arijske rase, te ekonomista i rasnog teoretičara Williama Z. Ripleyja (1867. 1941).

34

Za vrijeme Vajmarske Republike i pod vladavinom nacionalsocijalističkog totalitarizma na rasno-biološku nauku o mediteranizmu nadovezali su se liječnici, genetičari i eugeničari poput Eugena Fischera (1874. - 1967.) i Fritza Lenza (1887. - 1976.), uspostavljajući načela takozvane »rasne higijene«, pomoću koje je provedeno istrebljivanje Židova, Roma i Sintija te potlačivanje slavenskih naroda. Među njima se istaknuo i njemački filolog Hans Friedrich Karl Günther (1891. -1968.), koji se pored njemačkog pisca engleskih korijena Houstona Stewarta Chamberlaina (1855 - 1927.) nečasno proslavio kao suosnivač nacionalsocijalističke rasne ideologije. Svoje »nordijske misli« o »germanskoj vladarskoj rasi« iznio je u svom glavnom djelu pod naslovom Die Rassenkunde des deutschen Volkes (Rasna nauka njemačkog naroda) iz 1922. godine. Kasnije je zbog toga bio poznat i pod nadimkom Rassenpapst (Rasni Papa).

35

Giuseppe Sergi, The Mediterranean Race. A Study of the Origin of European Peoples, Walter Scott, London 1901., str. 254.

36

U Italiji slijedi politička zlouporaba misli iz polja rasne biologije od strane talijanskog fašizma pod Mussolinijem, koji je jednostavno preokrenuo ravnotežu snaga između mediteranske rase $\mathrm{i}$ ostalih rasa $\mathrm{u}$ korist ove prve. U svezi s time, zanimljivo je navesti i činjenicu da je William Edward Burghardt DuBois (1868. - 1963.), afroamerički pisac, povjesničar, sociolog i zagovaratelj istih građanskih prava za sve bez obzira na rasnu pripadnost, koristio način sličan Sergijevu da bi dokazivao da ne postoje rasno-biološke razlike između bijelaca i crnaca u političkoj borbi protiv bijelih suprematista. 
osvajanja Sredozemlja, pojavljuje se promicanje interkulturalnog razumijevanja različitih pojedinaca i skupina bez obzira na jezičnu i narodnu pripadnost te vjeroispovijest. ${ }^{37}$ Pritom Herder ima u vidu neovisne talijanske gradove države s trgovačkim lukama, Genovu i Veneciju. On posebice skreće pažnju na njihovu slavnu povijest od početka 11. stoljeća do sudbonosne 1797. godine kad prestaju postojati, a nakon što je Napoleon prisilio Austriju da pristane na mirovinski ugovor u Campoformiju. ${ }^{38} \mathrm{~S}$ obzirom na građanski liberalizam za vrijeme prosvjetiteljstva, treba istaknuti da Herder iz svoje rasprave izostavlja sva pitanja o zlouporabi moći i nasilju u trgovačkom kolonijalizmu i imperijalizmu. Postaje upitno može li kulturna imaginacija o vladavini neovisnih talijanskih gradova država nad dijelom Sredozemlja, a u okvirima filozofije povijesti, zaista poslužiti kao uzor i primjer za interkulturalno razumijevanje uz poštivanje alijeniteta, bez zlouporabe moći i nasilja, u svrhu svjetskog mira.

Za razliku od Herdera, Georg Wilhelm Friedrich Hegel (1770. - 1831.) u svojim predavanjima o filozofiji svjetske povijesti ističe da je Sredozemlje u središtu staroga svijeta među Azijom, Europom i Afrikom, gdje su na okupu i tri svjetske religije židovstvo, kršćanstvo i islam. Sredozemlje je, po Hegelovu mišljenju, služilo kao »lako sredstvo za komunikaciju«. ${ }^{39}$ Sredozemlje je kulturološki gledano $»$ srce $\aleph^{40}$ starog svijeta. Bez njega ne bi bilo svjetske povijesti, kao što bez »foruma «, ${ }^{41}$ središta susreta svih žitelja, ne bi bilo ni Atene i Rima. Za razliku od gora i dolina, more je, po Hegelovu i Herderovu mišljenju, pokretač kako trgovanja i ratovanja, tako i kulturnog oživljavanja i interkulturalnog povezivanja. Sredozemno more, zemljopisno gledano kao more, za razliku od gorskih i dolinskih krajeva, zauzima središte starog svijeta:

"Samo zbog toga što je more, Sredozemlje je moglo postati središte. $\mathbb{1}^{42}$

Hegel zapaža antropološki značaj mora. Ono čovjeku daje predodžbu neodređenosti, neograničenosti i beskrajnosti u smislu starogrčke riječi thalassos. Ohrabruje ga da nadiđe svoje granice i da se odvaži kako na zaradu i dobit tako i na osvajanje i razbojstvo. Dok život u dolinama čovjeka veže za zemlju i s time povezane mnogobrojne ovisnosti i ograničenja, pomorski život ga, s jedne strane, oslobađa, no, s druge strane, izlaže ga opasnostima, velikim i teškim gubitcima za život i posjed. ${ }^{43}$ Upravo ta opreka i proturječnost sredstava i svrhe daje pomorskom trgovcu priliku da dokaže svoju hrabrost i plemenitost. Naime, ako je more, kako Hegel piše, »najnesigurniji i najlažljiviji element « ${ }^{44}$ za golo preživljavanje i poslovni uspjeh potrebni su pamet i razum, a lukavstvo prije svega. More je, po Hegelovu mišljenju, osjetilno, osjećajno i spoznajno podvojeno. Upravo u njegovim svojstvima mekoće, nedužnosti, bezazlenosti, popustljivosti, prijaznosti i podatljivosti sadržani su moć, sila i opasnost. ${ }^{45}$ Hegel nadalje ističe egzistencijalnu situaciju pomorca pri susretu s varljivim, nasilnim morem, ploveći u »jednostavnom komadu drveta«, oslanjajući se nasred beskrajne, neizmjerne i nepregledne površine ni na što drugo do na umjetno tlo pod nogama i na svoje ograničene ljudske snage. ${ }^{46}$

Hegel u pogledu na visoke kulture starog doba bilježi da Indijci i Kinezi nikada nisu osvajali mora u svom okruženju, ${ }^{47}$ dok se Perzijsko Carstvo protezalo sve do Sredozemnog mora. ${ }^{48}$ Nadalje, piše da su Sirijci, Feničani i Grci, kao vješti pomorci, trgovci i pustolovi, osvajali dijelove Sredozemlja, ${ }^{49}$ dok su Egipćani prisvajali zemlju u teškoj borbi protiv moćnog i silnog mora i da su oplodili zemlju izgradnjom sustava kanala za navodnjavanje na ušću rijeke Nil. ${ }^{50}$ Ističe i da su stari Grci u interkulturalnoj razmjeni Sredozemljem po- 
ticali svoj vlastiti duhovni razvoj, ${ }^{51}$ a da je Rimsko Carstvo postalo $/$ srednja zemlja obrazovanja«, nakon što je kao prva visoka kultura zavladalo Sredozemljem u cijelosti. ${ }^{52}$ Treba naglasiti da, po Hegelovu mišljenju, stari Grci pripadaju starom svijetu istočnog Sredozemlja, koje čini rubno područje starog svijeta Orijenta pod vladavinom Perzijskog Carstva. Po pitanju europskih korijena iz starog doba ovdje su diskurzivne formacije mediteranizma i orijentalizma istovremeno suprotstavljene i nerazdvojive.

Objašnjavajući novo doba, Hegel smatra da Englezi nisu dostigli visoku razinu kulture iako su tijekom 17. i 18. stoljeća, zauzimajući rt Gibraltar, zavladali ne samo Sredozemnim morem, nego i svim svjetskim oceanima. Međutim, »trgovački duh« Engleza širom svijeta uspostavlja ništa drugo doli »civilizacijske misije $\ll,{ }^{53}$ umjesto da postigne razinu visoke kulture. Kao i u slučaju Herdera, ovdje se postavlja kritičko pitanje može li kulturna imaginacija Sredozemlja kao središta visokih kultura iz staroga doba poslužiti kao uzor i primjer za interkulturalno razumijevanje alteriteta, uz poštivanje alijeniteta, bez zlouporabe moći i nasilja, a u svrhu svjetskog mira. Štoviše, to kritičko pitanje postaje složenije uzmemo li u obzir to da Hegel predviđa uskrsnuće svjetskog duha u »germanskom« odnosno prusko-njemačkom, a možda zatim i u »slavenskom« obliku. ${ }^{54}$

Na kulturnu imaginaciju Sredozemlja kao središta srednjovjekovnog doba, po Herderovu mišljenju, odnosno staroga doba, po Hegelu mišljenju, nadovezuje se, među ostalima, i Friedrich Nietzsche (1844. - 1900.). Sredozemlje spominje u petoj knjizi svoje aforističke zbirke pod nazivom Fröhliche Wissenschaft (La gaya scienzia, Radosna znanost) iz 1882. odnosno 1887. godine. ${ }^{55}$ Pritom mu lutanja glavnog lika iz Homerove Odiseje služe kao poetski obrazac za promišljanja o lutanju europskog duha. Po pitanju kulturnih ima-

37

Johann Gottfried Herder, Ideen zur Philosophie der Geschichte der Menschheit, sv. 2, Aufbau Verlag, Berlin - Weimar 1965., str. 440 .

38

Ibid., str. 442

39

Georg Wilhelm Friedrich Hegel, Vorlesungen über die Philosophie der Geschichte, u: Georg Wilhelm Friedrich Hegel, Werke, sv. 12, Suhrkamp, Frankfurt na Majni 1986., str. 115.

40

Ibid.

41

Ibid.

42

Ibid., str. 118 .

43

Ibid., str. 118f.

44

Ibid., str. 119.

45

Ibid.
46

Ibid., str. 118f.

47

Ibid., str. 192

48

Ibid., str. 231

49

Ibid., str. $233 \mathrm{ff}$.

50

Ibid., str. 248

51

Ibid. str. $277 \mathrm{ff}$.

52

Ibid., str 372.

53

Ibid., str. 538 .

54

Ibid. str. 133.

55

Friedrich Nietzsche, Radosna znanost (»La gaya scienzia«), prev. Davor Ljubimir, Demetra, Zagreb 2003. 
ginacija Sredozemlja, u ključnom aforizmu broj 382, Nietzsche uspoređuje duhovni prostor Europe, $\mathrm{tj}$. »sumu zapovjedanih vrijednosnih sudova, koji su nam prešli u meso i krv «, ${ }^{56} \mathrm{~s} »$ idealnim Mediteranom $\ll .{ }^{57}$ Nietzsche na jednom mjestu poziva filozofe budućnosti da budu »dobri Europljani $\aleph^{58}$ i da izbore »veliko zdravlje $\ll{ }^{59} \mathrm{Na}$ drugom mjestu poziva ih da stvaranjem novih vrijednosti u ulozi »argonauta ideala«, koji imaju pred očima »neotkrivenu zemlju čije granice još nitko nije sagledao, neku s-onu-stranu svih dosadašnjih zemalja i zakutaka ideala «, ${ }^{60}$ prevladaju staru europsku metafiziku i suvremenu europsku dekadenciju. Pritom bi se trebali, po Nietzscheovu mišljenju, u duhu pjesničke i misaone ironije poigravati svim dosad poznatim vrijednostima, ne bi li naposljetku spoznali »ideal nekog ljudsko-nadljudskog dobrog osjećanja i dobrohotnosti, koji će dosta često izgledati neljudskim« ${ }^{61}$ Njihova »parodija« postaje »velika ozbiljnost« u trenutku kada »započne tragedija « ${ }^{62}$ čiju će mudrost Nietzsche pjesnički iskazati tek u svom kapitalnom djelu Also sprach Zarathustra (Tako je govorio Zarathustra) iz 1883. - 1885. godine. ${ }^{63}$

U međuvremenu, Nietzsche uzima za uzor i primjer srednjovjekovno pjesništvo provansalskih trubadura i pjesmama samog sebe inscenira pod imenom Prinz Vogelfrei, tj. kao kraljevića slobodnog kao ptica na grani, a u ulozi izopćenika oslobođenog od svih pravila koja vrijede u građanskom i dvorskom svijetu, koji uživa u slobodnoj umjetnosti pjesništva ${ }^{64}$ Pritom Nietzsche stvara pojednostavljenu i zbog toga izrazito sumnjivu dihotomiju između europskih Sjevernjaka i Južnjaka. Po njoj, u kontinentalnom svjetonazoru i načinu življenja navodno prevladava samo ozbiljnost, kao da u životu sjeverno od Alpa ne postoje nikakve radosti. Na tom tragu, Nietzsche oštro polemizira s luteranskim protestantizmom, uspoređujući ga sa »seljačkom pobunom duha«, koji nalazi filozofijski nastavak u pesimizmu i romantizmu Arthura Schopenhauera (1788. - 1860.), odnosno umjetnički nastavak u glazbenoj drami Richarda Wagnera (1813. - 1883.). ${ }^{65}$ Naspram svega toga, u mediteranskom svjetonazoru i načinu življenja navodno prevladava samo razigranost, kao da u životu na Sredozemlju ne postoje nikakve poteškoće. Čini se da Južnjaci, uživajući u jednostavnim radostima, žive u nevinosti i lakoći. Južnjaci su za Nietzschea pjevači i ljubavnici ili osvajači i stvaratelji za razliku od Sjevernjaka, koje uspoređuje s tragačima za istinom u obliku ružne starice. ${ }^{66}$ Ispada da su Južnjakinje sve redom ljepotice.

Treba uzeti u obzir da Nietzsche u Radosnoj znanosti zagovara interpretacijski relativizam:

»Svijet nam je [...] postao ‘beskonačnim': utoliko što ne možemo odbaciti mogućnost da on u sebi uključuje beskrajne interpretacije. ${ }^{67}$

Očito i sam Nietzsche kao jedan od mediteranskih »argonauta ideala« stječe iskustvo uzvišenosti pod dojmom beskrajnosti i neizmjernosti Sredozemnog mora u smislu starogrčke riječ thalassos. No, kritički će promatrač - s lakoćom kraljevića izopćenika, po Nietzscheovu mišljenju, slobodnog kao ptica na grani - s obje strane europske dihotomije, sa Sjevera i s Juga, uočiti cijeli niz osjetilnih, osjećajnih i spoznajnih opreka i proturječnosti. Primjerice, nije jednoznačno razlučivo pripadaju li isključivo Sjeveru ili Jugu, odnosno Europi ili Sredozemlju ozbiljnost ili razigranost, razum ili um, tijelo ili duša i duh, zdravlje ili bolest, sloboda ili sluganstvo, junačko pomorstvo ili brodolom, bezbožnost ili novi bogovi. 
U raspravi o La crise de l'esprit, krizi duha, a podrazumijeva se da je tu riječ o europskom duhu, iz 1919. godine, Paul Valéry (1871. - 1945.) u istočnom Sredozemlju prepoznaje »jednu vrstu predvorja Europe«, te ističe:

$»$ Kelti, Slaveni i germanski narodi osjetili su čar tog najplemenitijeg mora. Neka vrsta tropizma za Jugom, koja je potrajala nekoliko stoljeća, pretvorila je Sredozemlje sa svojim čudnovatim oblikom u predmet opće požude i poprište najjačeg razvitka ljudske snage. $\aleph^{68}$

Valéry naglašava da Sredozemlju, u usporedbi sa svim drugim svjetskim morima, pripada posebna plemenitost, što je stari topos i tropos europske kulture. Nije jednoznačno razlučivo predstavlja li pritom Sredozemlje, koje je ishodište europske kulture, alteritet ili alijenitet, odnosno predstavlja li ono uistinu iskonsku vlastitost i svojstvenost Srednjoj Europi. Osim toga, poetski i estetski gledano, nije jednoznačno razlučivo predstavlja li pritom Sredozemlje ljepotu ili uzvišenost. Ono je svejedno izvor nadahnuća i stvaralaštva na svim područjima ljudske djelatnosti. Stoga je Sredozemlje predmet kako zemljopisnog i povijesnog, tako i društvenog i kulturnog divljenja te medij pomoću kojega Srednja Europa može shvaćati, određivati i poistovjećivati samu sebe. Sredozemlje trajno postaje rezonantni prostor za srednjoeuropsko pjesničko i misliteljsko pismo. Što se tiče osjetilnih, osjećajnih i spoznajnih opreka i proturječnosti, alžirsko-francuski filozof Jacques Derrida (1930. 2003.) primjećuje da Sredozemlje, kako ga Valéry zamišlja, sadrži u sebi retoričke, poetske i logičke aporije centra i periferije Srednje Europe. ${ }^{69} \mathrm{Na}$ tom tragu, hrvatski germanist Ivan Pederin (1934. - ) može usporediti sredozemna područja poput Toskane, Kastilje ili Dalmacije sa »žilom kucavicom Europe . $^{70}$ Povijesno gledano, ona zauzimaju središte europskog duha, dok zemljopisno gledano pripadaju kontinentalnom rubu.

Uoči Prvog svjetskog rata, njemački književnici, a to su, među ostalima, Gerhart Hauptmann (1862. - 1946.), Hermann Bahr (1863. - 1934.) i Thomas Mann (1875. - 1955.), poput Nietzscheovih »argonauta ideala« na »idealnom

56

Ibid., aforizam br. 380, str. 224.

57

Ibid., aforizam br. 382, str. 226.

58

Ibid., aforizam br. 376, str. 222

59

Ibid., aforizam br. 382, str. 226 .

60

Ibid.

61

Ibid., str. 227

62

Ibid.

63

Friedrich Nietzsche, Tako je govorio Zaratustra. Knjiga za svakog i ni za koga, prev. Danko Grlić, Moderna vremena, Zagreb 2001.

64

F. Nietzsche, Radosna znanost, str. 229-241.
65

Ibid., aforizam br. 99, str. 89f., aforizam br. 357 i 358 , str. $197 \mathrm{ff}$. te aforizam br. 370 , str. $214 \mathrm{ff}$.

66

Ibid., str. 8, predgovor drugom izdanju.

67

Ibid., aforizam br. 374, str. 219.

68

Paul Valéry, »Die Krise des Geistes«, u: Paul Valéry, Werke, sv. 7, Insel, Frankfurt na Majni - Leipzig 1995., str. 26-54, str. 43f.

69

Jacques Derrida, Das andere Kap. Die vertage Demokratie. Zwei Essays zu Europa, Suhrkamp, Frankfurt na Majni 1992., str. $31 \mathrm{ff}$.

70

Ivan Pederin, »Dalmatien-Kroatien als Schlagader Europas«, u: Tomislav Zelić, Zaneta Sambunjak, Anita Pavić Pintarić (ur.), Europa? Zur Kulturgeschichte einer Idee, Königshausen \& Neumann, Würzburg 2015., str. 33-44. 
Mediteranu«, stvaraju, svatko svoju, inačicu književnog mediteranizma. Dok Hauptmann i Bahr plove parobrodom duž obale Istočnog Jadrana do Atene odnosno do Boke kotorske, Th. Mann putuje vlakom od Münchena do Pule, a zatim trajektom na Brijunski arhipelag. Putovanje ga naposljetku vodi u Veneciju. U svom putopisu, Hauptmann, među ostalim, postavlja i paradoksalnu tvrdnju da je Grčka u obliku primus inter pares istovremeno duhovno prisutna u svim europskim provincijama i glavna provincija Europe.$^{71}$ Pogled na gore Parnas i Helikon preplavi književnika čežnjom da »se sve rijeke s ovih svetih brda opet bogato i svježe pretaču u odumrla područja europske duše «. ${ }^{72}$ Hauptmann svjesno slijedi duhovne putove helenista iz Goetheova doba u pokušaju da oživi njemačku kulturu na temelju njene navodne srodnosti sa starogrčkom kulturom. Međutim, smatra da je on sam u prednosti jer, za razliku od helenističkih idealista iz Goetheova doba, doista putuje u Grčku. Štoviše, nada se da će mu stvarni doživljaj sredozemnog krajolika razotkriti tajne starogrčke kulture. Dakle, Hauptmann povezuje stada koza na krševitom priobalju i razgledavanje Elisijskog polja i brdskog kazališta pokraj Delfija s Posejdonom, Dionizijem, Demetrom i s nastankom tragedije iz obreda žrtvovanja u slavu i čast tih božanstava. Oštroumno Hauptmann sagledava stvarno stanje siromaštva, jada i bijede u suvremenom velegradu Ateni te zaostalost i nazadnost $u$ ponašanju seljačkog stanovništva bez da upada $u$ stereotipe balkanizma u smislu Todorove. Naprotiv, Hauptmann ističe da se u seoskim sredinama u Grčkoj živi u skladu s prirodom, nakon što je ta mlada država tek oslobođena od tuđinske vlasti pod Osmanskim Carstvom. Putopis je $u$ cijelosti podvojen s obzirom na neohelenistički misticizam u pogledu na starogrčku kulturu i na modernistički naturalizam u odnosu na suvremeni velegrad i selo. Međutim, interkulturalno razumijevanje alteriteta uz poštivanje alijeniteta nailazi na nepremostive prepreke. Naime, Sredozemlje, kako ga Hauptmann prikazuje, podijeljeno je na baštinu iz starog doba i na prirodni i velegradski krajolik suvremenog doba tako da istovremeno predstavlja kulturno ishodište i barbarski ponor za Srednju Europu.

U svom neobičnom putopisu Dalmatinsko putovanje iz 1909. godine, austrijski pisac Hermann Bahr, ${ }^{73}$ inače poznat kao austrijski kritičar europske avangarde ${ }^{74}$ predlaže iscrpnu modernizaciju. U duhu građanskog liberalizma, Bahr predviđa obnovu na svim poljima ljudske djelatnosti, od gospodarstva, pravosuđa i državne uprave do odgoja i obrazovanja, znanosti i umjetnosti, ne samo u austrijskoj kraljevini Dalmaciji nego i Austro-Ugarskom Carstvu u cijelosti. Pritom Bahr polazi od kulturne imaginacije da Austrija, odnosno austrijska prijestolnica Beč, duhovno gledano predstavlja Aziju, u smislu orijentalizma s negativnom konotacijom, kako smatra Said, dok Dalmacija predstavlja iskonsku Europu na Sredozemlju, u smislu književnog mediteranizma s nadasve pozitivnom konotacijom. Mediteransku provinciju na periferiji carstva treba uistinu zemljopisno, povijesno i kulturno shvatiti kao ishodište i središte europskog duha, koji će Austro-Ugarsko Carstvo obnoviti od samih temelja. Pritom je paradoksalno da Dalmacija istovremeno predstavlja primjer i uzor, kako za austro-ugarsku multikulturalnost prema »habsburškom mitu« ${ }^{75}$ tako i za europsku interkulturalnost i transkulturni kozmopolitizam. No, kulturna imaginacija da je Dalmacija poetski topos, tropos i figura srednjoeuropskog Sredozemlja sadrži cijeli niz osjetilnih, osjećajnih i spoznajnih opreka i proturječnosti. Postavlja se ponovno kritičko pitanje o tome je li uopće moguće interkulturalno razumijevanje alteriteta, uz poštivanje alijeniteta, bez zlorabljenja moći i nasilja, u svrhu interkulturalnog mira. Primjerice, Bahr, koji nije poznavao nijedan slavenski jezik, smatra sebe pravednim glasnogovor- 
nikom dalmatinskog naroda. Svoje znanje o Dalmaciji crpi, prije svega, iz drugih putopisa, odnosno iz svojih korespondencija s posrednicima, među ostalima, i češkim književnikom Jaroslavom Kvapilom (1868. - 1950.). ${ }^{76}$

U svojoj svjetski poznatoj noveli pod naslovom Smrt u Veneciji iz 1912. godine, Thomas Mann ${ }^{77}$ stvara cijeli niz složenih topografskih odnosno topologijskih i tropologijskih rekonfiguracija Sredozemlja odnosno Venecije. Osim toga, suprotstavlja Srednju Europu i Sredozemlje na višestruki način, prema pravilima triju spomenutih diskurzivnih formacija: balkanizam, orijentalizam i mediteranizam. Glavni lik Gustav pl. Aschenbach, češko-pruski pedesetogodišnjak, koji slovi kao svjetski poznati književnik, pod dojmom je iskušenja pederastije $u$ tajnom ljubavnom odnosu s poljskim mladićem i plemićem Tadziom i istovremenim prodorom epidemije »indijske kolere « preko Sredozemlja u Srednju Europu. Njegova, odnosno pripovjedačeva kulturna imaginacija Sredozemlja sadrži izrazito širok spektar poetskih rekonfiguracija. Sredozemlje, odnosno Venecija predstavlja, među ostalim, i Arkadiju i Elisijska polja, ishodište europske umjetnosti, religije i znanosti, finis terrae pod vječnim sjajem sunca te neku vrstu satiričkog filmskog projektora za neoklasicistički amblem savršene ljepote, koju Aschenbach uočava u Tadziju. No, kratki pogled u pravcu Balkana otkriva kulturnu podvojenost Istre kao pograničnog područja Sredozemlja i Srednje Europe. Tamošnje slavensko i talijansko stanovništvo u austrijskoj ratnoj i putničkoj luci Puli i na Brijunskom arhipelagu ispunjava sva obilježja balkanizma po Todorovoj. Opisivanje sredozemnog krajolika, međutim, slijedi obrasce poetskih hvalospjeva europskog mediteranizma.

»Stanovništvo tog otoka šareni su i odrpani seljaci, koji govore posve tuđim jezikom, a lijepe razgrađene hridine spuštaju se u more, ondje gdje je otvoreno. $\ll^{78}$

Nakon kratke istarske međuigre, putovanje vodi glavnog lika u pravcu Venecije, gdje će se čitateljstvo upoznati sa sasvim drugim oprekama i proturječnostima.

U europskoj tradiciji obrazovnih i kavalirskih putovanja, od renesanse nadalje, Venecija, stoljetni velegrad na laguni, mnemotopologijski je obilježen

71

Gerhart Hauptmann, Griechischer Frühling Reisetagebuch Griechenland - Türkei 1907, Propyläen, Frankfurt na Majni - Berlin 1996., str. 14

72

Ibid., str. 118.

73

Hermann Bahr, Dalmatinische Reise, S. Fischer, Berlin ${ }^{1} 1909$. Hrvatsko izdanje: Hermann Bahr, Dalmatinsko putovanje, prev. Benjamin Tolić, Grafički zavod Hrvatske, Zagreb 1991.

74

Usp. Martin Anton Müller, Claus Pias, Gottfried Schnödl (ur.), Hermann Bahr. Österreichischer Kritiker europäischer Avantgarden, Peter Lang, Bern et al. 2014. No, Bahr je također bio zapleten u rasnu biologiju. Usp. Tomislav Zelić (ur.), Traditionsbrüche. Neue Forschungsansätze zu Hermann Bahr, Peter Lang, Frankfurt na Majni et al. 2016.
75

Cladio Magris, Il mito absburgico nella letteratura austriaca moderna, G. Enaudi, Torino 1963.

76

O odnosu Bahra i Kvapila u pogledu na Dalmatinsko putovanje vidi: Kurt Ifkovits, »Hermann Bahrs Dalmatinische Reise aus textgenetischer Sicht«, u: Tomislav Zelić (ur.), Traditionsbrüche. Neue Forschungsansätze zu Hermann Bahr, Peter Lang, Frankfurt na Majni et al. 2016., str. 119-137, prije svega str. 122.

77

Thomas Mann, Smrt u Veneciji. Pripovijetke, prev. Oto Š́lc, Libar, Zagreb 1979., str. 187-258.

78

Ibid., str. 200f. 
kao počivalište slavne Mletačke Republike, koja je čvrsto vladala Jadranskim morem od 11. stoljeća do 1797. godine. Ovdje mladi plemići i bogati mladi građani prisvajaju europsku baštinu u obliku građevina, kazališnih i glazbenih predstava te posjetima mnogobrojnim umjetničkim galerijama i muzejima. Mjesto radnje, Grand Hotel des Bains na Lidu, nalazi se na samom rubu Srednje Europe i Sredozemlja te predstavlja višestruku »heterotopiju« i »heterokroniju « ${ }^{79}{ }^{\mathrm{U}} \mathrm{U}$ pionirsko doba modernog masovnog turizma to je ljetovalište tekovina svjetske kulture, vrhunac ljudske slobode pojedinca i zajednice, makar samo u vrijeme odmora. Osim toga, dok se uoči Prvog svjetskog rata pojačava zveckanje oružja europskih velesila, ljetovalište također predstavlja utočište srednjoeuropskog kozmopolitizma, međunarodnog razumijevanja i svjetskog mira, bar kao »iluzija« ili »kompenzacija« u smislu »kronične heterotopije $\ll{ }^{80}$ Sve su interkulturalne razlike na tom mjestu iznimno pomirene, prema nepisanim transkulturnim pravilima odijevanja i ophodnje. Interkulturalni odnosi uređeni su u skladu sa staležom kojemu pojedinac pripada. Međutim, to vrijedi isključivo na razini hotelskih gostiju, koji redom potiču iz plemstva, visokoobrazovanog i imućnog građanstva i pripadaju sloju suvremenog društva gdje još postoji transkulturno jedinstvo čovječanstva i svijeta. Ipak, Sredozemlje u nestvarnom obliku noćne more glavnog lika sadrži u sebi distopijsku teofaniju odnosno epifaniju. Naime, pripadnici transhumantnog stočarstva ${ }^{81}$ spuštaju se sa svojih gora na sredozemnu obalu i tamo izazovu "sveopće komešanje ${ }^{82}$ te održavaju svoje obrede nasilja i ubojstva na slavu i čast »stranog boga ${ }^{83}$ Dionizija porijeklom iz Male Azije. U toj noćnoj mori zasigurno se višestruko isprepleću kulturni stereotipi s negativnom konotacijom orijentalizma, kako smatra Said, odnosno balkanizma, kako smatra Todorova, ali isto tako i u smislu mediteranizma.

Međutim, kulturna imaginacija Sredozemlja, alijeniteta u obliku bluda, razvrata i nećudorednosti, zaista zavlada društvenim životom nakon što u Veneciji izbije zarazna i smrtonosna bolest, »indijska kolera « ${ }^{84}$ Posljedično, mediteranski velegrad na laguni u izvanrednom stanju epidemije postepeno poprima sva obilježja orijentalizma, kako smatra Said:

»... korupcija viših zajedno s vladajućom nesigurnošću, izuzetno stanje, u koje je pohod smrti stavio sav grad, sve je to dovelo do izvjesnog pada morala u nižim slojevima, ohrabrilo tamne i nesocijalne nagone, a to se sve pokazuje u neumjerenosti, bestidnosti, [porastu] kriminaliteta. Protiv svih pravila primijećeni su navečer mnogi pijanci; opak ološ, priča se, čini noću ulice nesigurnima; razbojnički se napadaji, čak i slučajevi umorstva, ponavljaju, jer već se dvaput dokazalo, da su ljudi, koji su tobože umrli od zaraze, ustvari umoreni otrovom; zanatski razvrat poprima nametljive i raspusne oblike, koji su do tada bili nepoznati u Veneciji, koji su bili odomaćeni jedino na jugu zemlje i na Orijentu. $\ll^{85}$

Usprkos poetici i estetici uzvišenosti i užasa u pogledu na beskrajnost, neizmjernost i nepreglednost Sredozemnog mora u obliku nemani i grdosije, koja u više navrata izaziva talasofobiju glavnog lika, Sredozemlje, u apokaliptičkom raspoloženju esteticizma, u doba secesije, uoči Prvog svjetskog rata, sadrži u sebi i obećanje »velikog zdravlja«, uskrsnuća i vječnog života u nekoj na poznat način nepoznatoj budućnosti. Posljednja scena Smrti u Veneciji donosi višestruku osjetilnu, osjećajnu i spoznajnu opreku i proturječnost u topografskoj odnosno topologijskoj i tropologijskoj rekonfiguraciji Sredozemlja u obliku »maglovite beskonačnosti ${ }^{86}{ }^{86}$ sto označava zauvijek nepreglednu i nedokučivu prošlost i sadašnjost. No Tadzio, »mili psihagog $«,{ }^{87}$ duševni i duhovni vodič, upućuje ne samo umirućeg glavnog lika, nego i čitateljstvo na Sredozemlje u obliku »neizmjernosti pune obećanja« ${ }^{88}$ Neizvjesnost budućnosti sadrži i eshatološke mogućnosti boljitka, obnove života i spasenja, 
dapače, došašće Boga, uskrsnuće i vječni život, usprkos očiglednoj pogibiji Srednje Europe.

Naposljetku, treba naglasiti da novela Th. Manna Smrt u Veneciji, među svim spomenutim književnim djelima nastalima uoči Prvog svjetskog rata, najbolje prikazuje složene i višestruke osjetilne, osjećajne i spoznajne opreke i proturječnosti u kulturnim imaginacijama Sredozemlja. Povrh toga, istovremeno su istaknute i suprotstavljenost $\mathrm{i}$ isprepletenost diskurzivnih formacija orijentalizma, balkanizma i mediteranizma. Dakle, prepreke, koje neophodno nastaju u svim pokušajima interkulturalnog razumijevanja multikulturalnog alteriteta, uz dužno poštivanje alijeniteta, bez nasilničke zlouporabe moći, u svrhu transkulturnog mira, postaju upravo predmetom i sadržajem ove pripovijetke.

\section{Zaključak}

Naposljetku, postavlja se pitanje o tome je li Mediteran prikazan s negativnim i pejorativnim konotacijama na sličan način kao što su to Orijent i Balkan ili tomu nije tako. Nadalje, postavlja se presudno pitanje jesu li, sa srednjoeuropskog stajališta, koje zauzimaju različiti autori, različitosti Mediterana drugačije od onih Orijenta i Balkana. Po tom pitanju ovdje možemo heuristički postaviti deduktivnu i djelomice induktivnu teorijsku hipotezu da Balkan uistinu utjelovljuje oprečnost, suprotnost i protivnost Europi, no uz napomenu da je Balkan za Europu unutarnji stranac, za razliku od Orijenta, koji je za Europu vanjski stranac i koji, po Saidovu mišljenju, svejedno igra unutarnju ulogu u Europi. Nadalje, Balkan je uistinu kolonijalističko i imperijalističko područje, no, ne toliko za europske velesile, koliko za Osmansko Carstvo, izuzmemo li Austriju i Njemačku u vrijeme Prvog i Drugog svjetskog rata i ostavimo li po strani mletački »polu-orijentalizam ${ }^{89}$ na istočnoj obali Jadranskog mora u 18. stoljeću. Zatim, za razliku od Orijenta, Balkan u pravilu ne slovi kao izvor europskih jezika i naroda unutar europskog diskursa, premda postoje znanstvena istraživanja koja ističu da nesumnjivo postoje dodiri i razmjene između starih južnoslavenskih i balkanskih jezika te starogrčkog jezika. ${ }^{90} \mathrm{Ui}$ stinu se Balkan natječe s Europom, unatoč tome što je, s europskog stajališta,

79

Michel Foucault, »O drugim prostorima«, prev. Stipe Grgas, Glasje 3 (1996) 6, str. 8-14.

80

Ibid.

81

Usp. »transhumantno stočarstvo«, Hrvatska enciklopedija, mrežno izdanje, Leksikografski zavod Miroslav Krleža, 2020. Dostupno na: http://www.enciklopedija.hr/Natuknica.aspx?ID=62039 (pristupljeno 2. 7. 2020.).

82

Th. Mann, Smrt u Veneciji, str. 250.

83

Ibid.

84

Ibid., str. 247.
85

Ibid., str. $248 f$.

86

Ibid., str. 257.

87

Ibid., str. 258

88

Ibid.

89

Nino Raspudić, Jadranski (polu)orijentalizam. Prikazi Hrvata u talijanskoj književnosti, Naklada Jurčić, Zagreb 2010.

90

Radoslav Katičić, The Ancient Languages of the Balkans, Mouton, Den Haag 1976. 
upravo onako kako je Orijent, podložan Europi. Konačno, Balkan je, kao i Orijent, odbačen od strane Europe, unatoč tome što je Balkan, kao i Orijent, istovremeno tvorben za način kako Europa zamišlja samu sebe. Međutim, zemljopisno gledano, Balkan je, za razliku od Orijenta, sastavan dio europskog kontinenta. Drugim riječima, dok je Orijent za Europu vanjski stranac i vanjska razlika, koja igra unutarnju ulogu, Balkan za Europu utjelovljuje unutarnju razliku i unutarnjeg stranca, koji, pomalo paradoksalno rečeno, preuzima ulogu vanjskog stranca i vanjske razlike unutar Europe.

Dakle, presudno je pitanje o tome kakvi su kulturni odnosi između Europe i Sredozemlja. Zemljopisno gledano, Europa i Sredozemlje oprečni su kao kopno i more. Međutim, kulturološki gledano, Sredozemlje postaje, sa srednjoeuropskog stajališta, ono što je unutarnje ili vanjsko svojstvo Europe, mare nostrum. No istovremeno je sasvim različito ili posve drugačije od Europe, ovisno o tome kojeg autora, koje djelo ili koju epohu tumačimo. Sredozemlje je, baš kao i Orijent, područje kolonijalizma i imperijalizma, grčkog i rimskog u staro doba, đenovskog i mletačkog u srednjem vijeku te britanskog u moderno doba. Za razliku od Balkana, Sredozemlje je, makar bilo pogranični prostor, uistinu uzor i primjer, dapače, iskonsko ishodište svih europskih jezika i naroda po europskoj tradiciji helenizma i latinizma. Sredozemlje, upravo kao Orijent, ali za razliku od Balkana, predstavlja vanjskog stranca i vanjsku razliku koja preuzima unutarnju ulogu u Europi. Sredozemlje se uistinu kulturno natječe s Europom, no treba pritom istaknuti da, premda Europa ponekad gleda na Sredozemlje podcjenjivački, baš kao i na Orijent i na Balkan, ${ }^{91}$ Europa u pravilu ne podcjenjuje Sredozemlje, što pak čini s Orijentom i Balkanom, već ga često, čak i patetično, veliča u poetskim i filozofijskim hvalospjevima, bilo nostalgično kao iskonsko ishodište Europe, bilo utopijski kao zamišljenu novu Europu.

U svakom slučaju, Sredozemlje slovi kao ono što tvori načine na koje Europa zemljopisno, povijesno i kulturno zamišlja samu sebe. To je u okvirima njemačke književnosti u moderno doba, u kasnom 18. odnosno ranom 20. stoljeću, izneseno s obzirom na Herdera, Hegela i Nietzschea odnosno Hauptmanna, Bahra i Th. Manna. Takve i slične poetske rekonfiguracije Sredozemlja $\mathrm{u}$ međuvremenu su pale $\mathrm{u}$ zaborav te bi ih se trebalo prisjetiti $\mathrm{i}$ to ne samo zbog takozvane gospodarske, izbjegličke ili pandemijske krize u Europi i na Sredozemlju odnosno širom svijeta. Povrh svega toga, mediteranističko europsko pismo ne oskudijeva, kako smo vidjeli, svojevrsnim osjećajnim i spoznajnim oprekama i proturječnostima, odnosno poetskim ironijama i logičkim paradoksima, koje bi trebalo podrobnije i potanje istražiti u zasebnim radovima o pojedinim autorima, opusima i epohama. 


\section{Tomislav Zelić}

\section{Mediterranismus - kulturelle Imaginationen des Mittelmeeres}

\section{Zusammenfassung}

Unter der Annahme, dass der Orientalismus und Balkanismus nicht einmal rudimentär die reichhaltigen interkulturellen Beziehungen zwischen Europa und dem Mittelmeer erfasst, argumentiert die vorliegende Forschungsarbeit, dass es nötig ist, einen weiteren Diskurs in Ermangelung einer besseren Bezeichnung unter dem Namen Mediterranismus einzubeziehen. Darunter sind kulturelle Imaginationen des Mittelmeeres als philosophische und poetische Denkfigur der europäischen Schriftkultur zu verstehen. Die Hauptaufgabe ist dabei auf der Grundlage der Begriffsgeschichte in Fragmenten und der Deduktion der heuristischen theoretischen Hypothesen eine Rekonstruktion und kontrastive und komplementäre Komparation dieser drei Diskursformationen durchzuführen, unter der Einsicht, dass sie unter den Bedingungen der Moderne bei der europäischen Selbstbesinnung zugleich entgegengesetzt und miteinander verwoben sind. Daher enthalten sie eine ganze Reihe von perzeptiven, affektiven und kognitiven Gegensätzen und Widersprüchen, die gesondert in weiteren Forschungsarbeiten zu untersuchen sind.

\section{Schlüsselwörter}

Europa, Mittelmeer, Literatur, Philosophie, Moderne, Deutschland, Österreich, Mediterranismus

Primjerice, takozvana europska dužnička kri$z a$ iz 2010. godine naovamo u jednom je trenutku produbila interkulturnu podjelu Europe između Sjevera i Juga, a ta podjela počiva na starim dihotomijama sjevernjačkog i južnjačkog svjetonazora i načina življenja između razumnosti i strastvenosti, štedljivost i raskoši itd. 